\title{
Bumblebee assemblages (Hymenoptera, Apidae) of ruderal habitats in the Kola Peninsula, NW Russia
}

\author{
Grigory S. Potapov', Yulia S. Kolosova' and Alexander V. Kondakov'
}

\begin{abstract}
Potapov GS, Kolosova YS and Kondakov AV. 2015. Bumblebee assemblages (Hymenoptera, Apidae) of ruderal habitats in the Kola Peninsula, NW Russia. Fauna norvegica 35: 3-8.

Bumblebee assemblages of ruderal habitats were studied in the Kola Peninsula in 2012. The number of species in the assemblages varies from 7 to 11. Of cryptic species Bombus sensu stricto in the Kola Peninsula only Bombus cryptarum was registered. The most abundant species in the study habitats are B. jonellus and B. cryptarum. Abundances of tundra species B. lapponicus, B. alpinus, B. balteatus are low in all localities. $B$. distinguendus and $B$. veteranus are southern immigrants in the region. Ruderal habitats in the Kola Peninsula are potentially important for bumblebee conservation.
\end{abstract}

doi: 10.5324/fn.v35i0.1837. Received: 2015-01-22. Accepted: 2015-05-17. Published online: 2015-10-06. ISSN: 1502-4873 (printed), 1891-5396 (electronic).

Keywords: Bombus Latr., fauna, bumblebee assemblages, ruderal habitats, Kola Peninsula

1. Institute of Ecological Problems of the North, Russian Academy of Sciences (Ural Division), Naberezhnaya Severnoy Dviny 23, Arkhangelsk 163000, Russia

Corresponding author: Grigory S. Potapov

E-mail: grigorij-potapov@yandex.ru

\section{INTRODUCTION}

At the present time there is a large body of data with respect to fauna of bumblebees in the northern parts of Finland, Norway and Sweden. These data have been summarised in a series of papers (Løken 1973, 1984; Pekkarinen et al. 1981; Söderman \& Leinonen 2003). Compared with other provinces of this region, the Kola Peninsula remains rather poorly studied. The great bulk of materials was collected in the late $19^{\text {th }}$ to early $20^{\text {th }}$ Centuries, primarily, along the Barents Sea coast of the Kola Peninsula (Rybachy Peninsula, Murmansk, Kildin Island, Yokanga River, etc.). However, records from this region are sporadic (Pekkarinen et al. 1981), which applies particularly to the central and southern parts of the Kola Peninsula, excluding the Khibiny Mountains (Fridolin 1936; Potapov \& Kolosova 2011). The ecology of bumblebees in this region was studied only in the 1930s, in the Khibiny Mountains (Fridolin 1936). Bumblebee assemblages in the other areas of the Kola Peninsula have not been studied, and the surrounding regions (the northern parts of Finland, Norway and Sweden) also are poorly studied in this respect. There are some data from papers of Pekkarinen et al. (1981), Ranta (1982), Pamilo et al. (1997), etc. Most of the Scandinavian research relates to the southern part of Fennoscandia.

The main aim of this study was to analyse bumblebee assemblages in the Kola Peninsula. We have focused on the research of ruderal habitats.

\section{MATERIAL AND METHODS}

Samples for this study were collected in the Kola Peninsula (Murmansk Province of Russia) during the summer of 2012 (Table 1, Figure 1). Bumblebees were caught with an entomological net from 4 localities:

1) Clover meadow-like field (locality I). It is located along the roadside on the outskirts of Pechenga Settlement. This locality is bordered by willow-shrub wetlands of Pechenga River, which are typical communities for the northern part of the Kola Peninsula in hydromorphic conditions (Koroleva 2006). 
2) Roadside with clover and willow-herb (locality II). This habitat is near Magnetity Station (Kola River). It is located along the roadside and bordered by birch forest.

3) Clover meadow-like field (locality III) is on the outskirts

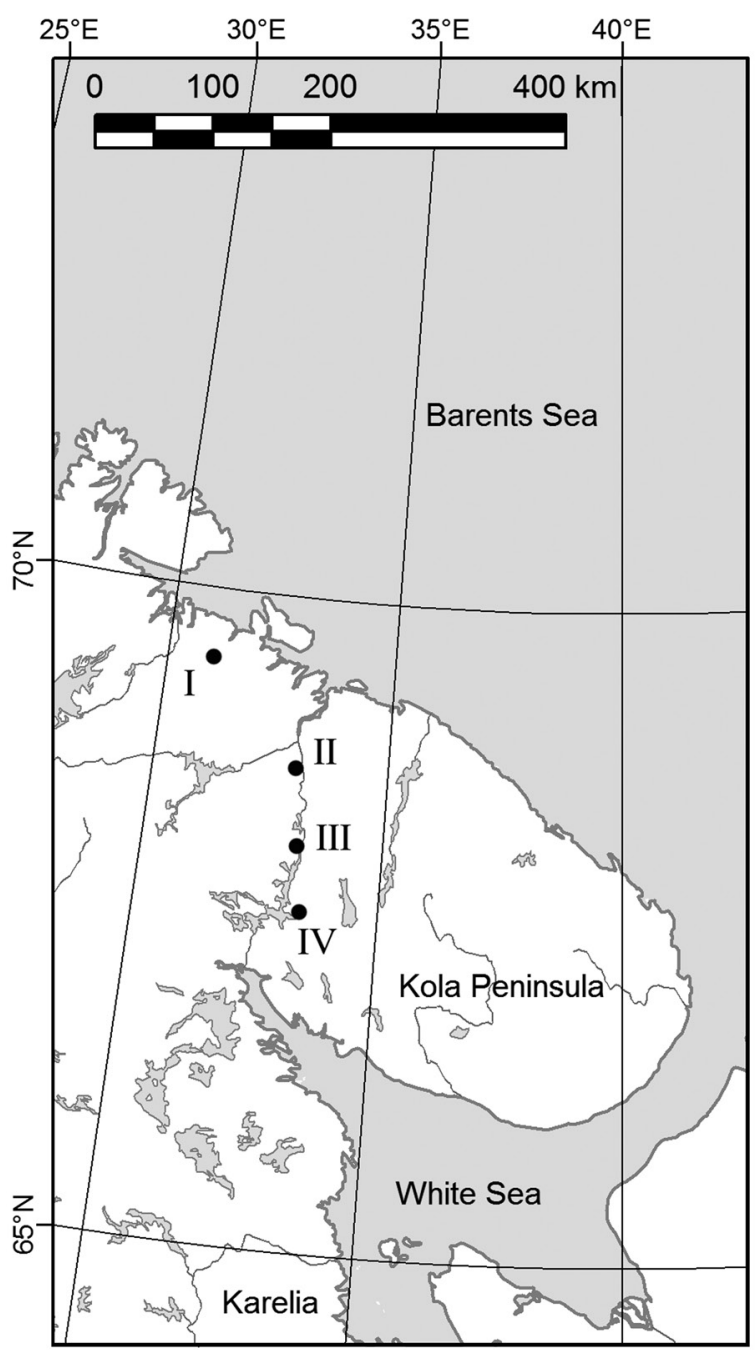

Figure I. The map of the study region. Sampling localities (dots): I - Pechenga Settlement, II - Magnetity Station, III - Olenegorsk Town, IV - Apatity Town. of Olenegorsk Town within the old industrial territory. At the present time, high anthropogenic pressure is discontinued.

4) Clover meadow-like field (locality IV). This locality is on the outskirts of Apatity Town. It is located near an urban road. The food plants of foraging bumblebees were identified according to Skvortsov (2000). The nomenclature of plants follows Elven (2014).

Bumblebees were identified by following Løken (1973, 1984) and Panfilov (1978). The subgeneric classification and the synonymy of species are given according to Williams (2014). Bombus lapponicus (Fabricius, 1793) and B. monticola (Smith, 1849) were distinguished according to Svensson (1979). Identification of cryptic species B. lucorum (Linnaeus, 1761), B. magnus Vogt, 1911, B. cryptarum (Fabricius, 1775) were conducted by Rasmont (1984, 1986, 2010). A total of 10 individuals of these species were studied by the use of DNA barcoding to confirm the morphological identification (Murray et al. 2008; Waters et al. 2011). Specimens are deposited in the Russian Museum of the Biodiversity Hotspots (RMBH), Institute of Ecological Problems of the North, the Ural Branch of Russian Academy of Sciences (IEPN UrB RAS), Arkhangelsk, Russia.

Molecular analysis was performed in the Institute of Ecological Problems of the North of UrB RAS (purification and PCR). We extracted genomic DNA from a single leg of each dry specimen using proteinase $\mathrm{K}$ and phenol, as described in Sambrook \& Russel (2001). The mitochondrial cytochrome oxidase subunit I gene (COI) was amplified and sequenced using primers C1-J-1718 and C1-N-2329R (Simon et al. 1994). The PCR mix contained approximately $200 \mathrm{ng}$ of total cell DNA, 10 pmol of each primer, $200 \mu$ mol of each dNTP, $2.5 \mu \mathrm{l}$ of PCR buffer (with $10 \times 2 \mathrm{mmol} \mathrm{MgCl}_{2}$ ), 0.8 units Taq DNA polymerase (SybEnzyme Ltd.), and $\mathrm{H}_{2} \mathrm{O}$ was added for a final volume of $25 \mu$ l. Temperature cycling was as follows: $95^{\circ} \mathrm{C}$ (4 min), 40 cycles of $95^{\circ} \mathrm{C}(50 \mathrm{sec}), 48^{\circ} \mathrm{C}(50 \mathrm{sec}), 72^{\circ} \mathrm{C}(50$ sec) and a final extension at $72{ }^{\circ} \mathrm{C}(5 \mathrm{~min})$. The sequencing was carried out at the facilities of the Inter-Institution Center of Group Use (Genom) (Engelhardt Institute of Molecular Biology of the Russian Academy of Sciences, Moscow) using the ABI PRISM $^{\circledR}$ BigDye $^{\mathrm{TM}}$ Terminator v. 3.1 reagents kit. Reaction products were analysed using an automatic sequencer $\mathrm{ABI}$

Table I. Description of the study localities.

\begin{tabular}{|c|c|c|c|c|}
\hline Code & Area & Coordinates & Habitats & Food plants \\
\hline I & Pechenga Settlement & $\begin{array}{l}69^{\circ} 28^{\prime} 50.9^{\prime \prime} \mathrm{N} \\
31^{\circ} 07^{\prime} 21.0^{\prime \prime} \mathrm{E}\end{array}$ & Clover meadow-like field & $\begin{array}{l}\text { Trifolium repens L., T. pratense L., Cirsium arvense } \\
\text { (L.) Scop., Scorzoneroides autumnalis (L.) Moench. }\end{array}$ \\
\hline II & Magnetity Station & $\begin{array}{l}68^{\circ} 41^{\prime} 05.6^{\prime \prime} \mathrm{N} \\
33^{\circ} 07^{\prime} 55.6^{\prime \prime} \mathrm{E}\end{array}$ & $\begin{array}{l}\text { Roadside with clover and } \\
\text { willow-herb }\end{array}$ & Chamerion angustifolium (L.) Holub, T. repens L. \\
\hline III & Olenegorsk Town & $\begin{array}{l}68^{\circ} 07^{\prime} 40.3^{\prime \prime} \mathrm{N} \\
33^{\circ} 17^{\prime} 25.8^{\prime \prime} \mathrm{E}\end{array}$ & Clover meadow-like field & T. repens L., T. pratense $\mathrm{L}$. \\
\hline IV & Apatity Town & $\begin{array}{l}67^{\circ} 34^{\prime} 39.2^{\prime \prime} \mathrm{N} \\
33^{\circ} 21^{\prime} 18.3^{\prime \prime} \mathrm{E}\end{array}$ & Clover meadow-like field & $\begin{array}{l}\text { T. repens L., T. pratense L., C. angustifolium (L.) } \\
\text { Holub. }\end{array}$ \\
\hline
\end{tabular}


PRISM $^{\circledR} 3730$ (Applied Biosystems). Obtained results were analysed using BioEdit 7.0.9 software (Hall 1999).

The sequences were submitted to NCBI Genbank (accession no. KP252261 - KP252270). Systematic positions of the sequences were retrieved from the BOLD system (Barcode of Life Data System) (Ratnasingham \& Herbert 2007).

The relative abundance of bumblebees was assessed by the proportion of individuals (Pesenko 1982). In addition, species abundance was calculated by means of the five-grade logarithmic scale (Pesenko 1982). The species, which have grade 4 or 5 are dominant, with grade 3 are common, and with grades 1 or 2 are rare (Bolotov \& Kolosova 2006). As diversity and dominance measures, we used Shannon (based on natural $\log$ ) and Berger-Parker indices (Magurran 2004). Indices were calculated by using the program Past Version 3.0.

Source of the map (Figure 1) is ESRI ArcGIS 10.0 software.

\section{RESULTS}

A total of 491 individuals of bumblebees belong to 15 species were found (Table 2). Of the 10 bumblebees identified by the aid of DNA barcoding, $100 \%$ were identified as B. cryptarum.
The number of species in the bumblebee assemblages varies from 7 to 11. The richest in species are assemblages in Pechenga, others are poorer and have 7 to 8 species.

Shannon index in all assemblages does not exceed 1.42 (Table 2). These values are not high for the continental northern taiga (Bolotov \& Kolosova 2006). Values of Berger-Parker index are $49-90 \%$, that is, the evidence that the assemblages have superdominant species. They are B. jonellus (Kirby, 1802), B. cryptarum, B. cingulatus Wahlberg, 1854 (grade 5 or 4 , according to logarithmic scale). Common species (grade 3) are B. pascuorum (Scopoli, 1763) (locality I) and B. flavidus Eversmann, 1852 (locality III). The rest of the presented species are characterised by low abundance in the assemblages (grade 1 or 2) (Table 2).

\section{DISCUSSION}

The bumblebee fauna of the Kola Peninsula and surrounding regions are reported to include 23 species (Løken 1973, 1984; Pekkarinen et al. 1981; Söderman \& Leinonen 2003; Rasmont \& Iserbyt 2014; Rasmont et al. 2015). We registered only 15 species (Table 2), because we focused the sampling of ruderal

Table 2. Relative abundance and diversity parameters of bumblebee assemblages from the Kola Peninsula.

\begin{tabular}{|c|c|c|c|c|c|c|c|c|}
\hline \multirow{3}{*}{ Species } & \multicolumn{8}{|c|}{ Localities* } \\
\hline & \multicolumn{2}{|l|}{ I } & \multicolumn{2}{|l|}{ II } & \multicolumn{2}{|l|}{ III } & \multicolumn{2}{|l|}{ IV } \\
\hline & Id & $B$ & Id & $B$ & Id & $B$ & Id & $B$ \\
\hline B. (Subterraneobombus) distinguendus Morawitz, 1869 & - & - & - & - & - & - & 0.9 & 1 \\
\hline B. (Megabombus) hortorum (Linnaeus, 1761) & - & - & - & - & - & - & 0.9 & 1 \\
\hline B. (Thoracobombus) veteranus (Fabricius, 1793) & - & - & - & - & - & - & 1.8 & 1 \\
\hline B. (Th.) pascuorum (Scopoli, 1763) & 10.5 & 3 & 0.9 & 1 & - & - & - & - \\
\hline B. (Psithyrus) bohemicus Seidl, 1837 & 0.6 & 1 & - & - & 0.9 & 1 & - & - \\
\hline B. (Ps.) flavidus Eversmann, 1852 & 1.9 & 1 & - & - & 15.2 & 3 & - & - \\
\hline B. (Pyrobombus) lapponicus (Fabricius, 1793) & 2.5 & 2 & 3.7 & 2 & 1.8 & 1 & - & - \\
\hline B. (Pr.) hypnorum (Linnaeus, 1758) & 0.6 & 1 & 4.6 & 2 & - & - & 0.9 & 1 \\
\hline B. (Pr.) pratorum (Linnaeus, 1761$)$ & 0.6 & 1 & 2.8 & 1 & - & - & - & - \\
\hline B. (Pr.) jonellus (Kirby, 1802) & 55.9 & 5 & 49.1 & 5 & 58.0 & 5 & 1.8 & 1 \\
\hline B. (Pr.) cingulatus Wahlberg, 1854 & - & - & 36.1 & 4 & 0.9 & 1 & - & - \\
\hline B. (Alpinobombus) alpinus (Linnaeus, 1758) & 1.9 & 1 & - & - & - & - & - & - \\
\hline B. (Al.) balteatus Dahlbom, 1832 & 1.9 & 1 & - & - & - & - & - & - \\
\hline B. (Bombus) sporadicus Nylander, 1848 & 3.7 & 2 & 0.9 & 1 & 0.9 & 1 & 3.7 & 1 \\
\hline B. (Bo.) cryptarum (Fabricius, 1775) & 19.9 & 4 & 1.9 & 1 & 22.3 & 4 & 90.0 & 5 \\
\hline Number of samples & 161 & & 109 & & 112 & & 110 & \\
\hline Number of species & 11 & & 8 & & 7 & & 7 & \\
\hline Shannon index, ln & 1.42 & & 1.24 & & 1.14 & & 0.46 & \\
\hline Berger-Parker index, \% & 56 & & 49 & & 58 & & 90 & \\
\hline
\end{tabular}

Explanations: ${ }^{*}$ - sampling localities; see Table 1; Id - relative abundance, $\% ; B$ - relative abundance, according to logarithmic scale of Pesenko (1982), grades. 
habitats and did not study the other habitats.

Of cryptic species B. lucorum, B. magnus, B. cryptarum, we identified only B. cryptarum (Table 2). Bombus cryptarum is found in all study habitats of the Kola Peninsula. It visits mainly Trifolium repens Linnaeus, 1753 and T. pratense Linnaeus, 1753.

Bombus cryptarum is a widespread species, and it is found across Europe, central Asia and western North America (Scriven et al. 2015). Bombus lucorum is recorded in Europe and central Asia (Scriven et al. 2015). Bombus magnus is common in Europe, especially in the Atlantic region; this species is unknown in Asia (Williams et al. 2012; Rasmont \& Iserbyt 2014). In Finland B. cryptarum is abundant in Northern Lapland, B. magnus is restricted, mainly, to the southern part of the country, and B. lucorum is common in southern and central parts of Finland (Pamilo et al. 1997). Bombus cryptarum supplant B. lucorum and B. magnus north of the Arctic Circle (Rasmont \& Iserbyt 2014).

Currently, information about ecology of these species is almost absent (Waters et al. 2011). Numerous works, including records of $B$. lucorum, actually refer to a complex of three distinct species (B. lucorum, B. magnus, B. cryptarum) which are usually not distinguished by entomologists (Waters et al. 2011). Recent studies in Britain show that B. cryptarum is abundant in regions where temperatures are lower, hence this species is common at northern latitudes (Scriven et al. 2015). Bombus cryptarum usually associates with cool upland and visits a broad range of food plants from many families (Waters et al. 2011).

Preference of B. cryptarum to territories with cool climate can explain its relatively high abundance in the Kola Peninsula. It seems that climatic conditions of the region restrict the presence of B. lucorum and B. magnus.

In the north of the Kola Peninsula (localities I-III) one of the dominant species is $B$. jonellus. It is associated with shrub tundra and moorlands (Alford 1975; Shvartsman \& Bolotov 2008). These types of ecosystems are well represented in the northern part of the Kola Peninsula (Alexandrova \& Yurkovskaya 1989). However, B. jonellus successfully inhabits ruderal habitats.

In the outskirts of Magnetity Station (locality II) one of the dominant species is $B$. cingulatus which belongs to a group of forest species (Bolotov \& Kolosova 2006). High abundance of this species is due to birch forest in proximity to the study habitat. It is creating suitable conditions for successful development of $B$. cingulatus colonies.

There are differences in the species composition between bumblebee assemblages. These differences have a connection with biogeographic zonation. From the south to the north in the Kola Peninsula $B$. distinguendus Morawitz, 1869 and $B$. veteranus (Fabricius, 1793) have disappeared and the arctic and subarctic species (B. balteatus Dahlbom, 1832, B. alpinus (Linnaeus, 1758), B. lapponicus (Fabricius, 1793)) have emerged. Bombus distinguendus and $B$. veteranus are considered as southern immigrants in northern Europe (Løken 1973; Shvartsman \& Bolotov 2008). In the late 20th Century, both species were recorded in the Kola Peninsula (Rasmont \& Iserbyt 2014). According to Rasmont et al. (2015), B. veteranus expanded its range toward the north. It seems that it is also true for $B$. distinguendus. Models of future species distribution (Rasmont et al. 2015) predict that $B$. distinguendus and $B$. veteranus will colonise the Kola Peninsula, the northern parts of Finland and Norway in the middle and late 21st Century.

Arctic and subarctic species extend through mountain chains to the south of the Kola Peninsula, due to the similarity of mountainous and tundra ecosystems. This pattern is shown for different groups of insects (Chernov \& Tatarinov 2006). For example, bumblebee fauna of the Khibiny Mountains includes all tundra elements, viz. B. lapponicus, B. polaris, B. alpinus, B. balteatus, B. hyperboreus Schönherr, 1809 (Fridolin 1936, Potapov \& Kolosova 2011). However, in the outskirts of Apatity Town (locality IV), located about 5 kilometres from Khibiny, these species are not found (Table 2). Tundra species prefer to avoid ruderal habitats.

Unlike ruderal habitats, bumblebee assemblages of undisturbed ecosystems (e.g. in the Khibiny Mountains) have not any southern species as $B$. distinguendus and $B$. veteranus, and are characterised by higher abundance of tundra species (B. lapponicus, B. polaris, etc.). Assemblages of ruderal habitats consist, mainly, of ubiquitous and boreal species and a number of southern immigrants. Abundance of arctic and subarctic species is low. The general pattern is that bumblebee assemblages of anthropogenic habitats in northern Europe are enriched by southern immigrants, which are absent in native taiga and tundra ecosystems (Shvartsman \& Bolotov 2008). It is also observed in the Kola Peninsula. Through time with vegetation succession, ruderal habitats can be restored to the zonal taiga ecosystems (Rabotnov 1992). In this case, bumblebee assemblages will be close to those in undisturbed habitats.

It seems that ruderal habitats in the study region are potentially important for bumblebee conservation. They usually have high flower abundance and plant species richness, so they can provide forage for a large number of bumblebee species (Ahrné \& Bengtsson 2009). It is also known in the taiga zone of northern Europe (Shvartsman \& Bolotov 2008).

\section{ACKNOWLEDGEMENTS}

This study was supported by the Federal Agency for Scientific Organisations (0410-2014-0025, 0410-2014-0028), the Ural Branch of Russian Academy of Sciences (14-5-NP-71, 15-125-3, 15-2-5-7), grants from the President of Russia (MD6465.2014.5) and the Russian Foundation for Basic Research (14-04-31044 mol_a). We are especially grateful to Tatiana V. Romanis and Svetlana E. Sokolova (Institute of the Ecological Problems of the North) for helping to collect materials. We are 
indebted to Mikhail Yu. Gofarov who supplied us with the map. Special thanks due to Dr. Matthew Copley for improving the language.

\section{REFERENCES}

Alexandrova VD, Yurkovskaya TK. 1989. Geobotanical zoning of Nechernozemie region in the European part of RSFSR. Leningrad. Nauka. 65 p. (In Russian).

Alford DV. 1975. Bumblebees. London. Davis-Poynter. 325 p.

Ahrné K, Bengtsson J, Elmqvist T (2009) Bumble Bees (Bombus spp) along a Gradient of Increasing Urbanization. PLoS ONE 4(5): e5574. doi:10.1371/journal.pone.0005574

Bolotov IN, Kolosova YuS. 2006. Trends in the formation of biotopic complexes of bumblebees (Hymenoptera, Apidae: Bombini) in northern taiga karst landscapes of the Western Russian Plain. Russian Journal of Ecology 37(3): 156-166. doi:10.1134/S1067413606030039

Chernov YuI, Tatarinov AG. 2006. Butterflies (Lepidoptera, Rhopalocera) of Arctic fauna. Zoologicheskii zhurnal 10: 12051229. (In Russian).

Elven R. 2014. Annotated Checklist of the Panarctic Flora (PAF). Vascular plants. Accessed: http://nhm2.uio.no/paf/

Fridolin VYu. 1936. Animal-plant community of Khibiny Mountains. Biocenotic research 1930-1935. Trudy Kolskoi bazy Akademii nauk SSSR 3: 1-295. (In Russian).

Hall TA. 1999. BioEdit: a user-friendly biological sequence alignment editor and analysis. Nucleic Acids Symposium Series 41: 95-98.

Koroleva NE. 2006. Zonal tundra of the Kola Peninsula - Is it reality or mistake? Vestnik MGTU 9(5): 747-756. (In Russian).

Løken A. 1973. Studies of Scandinavian bumblebees (Hymenoptera, Apidae). Norsk Entomologisk Tidsskrift 20(1): 1-218.

Løken A. 1984. Scandinavian species of the genus Psithyrus Lepeletier (Hymenoptera, Apidae). Entomologica Scandinavica $23: 1-45$.

Magurran AE. 2004. Measuring biological diversity. Blackwell Science Ltd. $215 \mathrm{p}$.

Murray TE, Fitzpatrick U, Brown MJF, Paxton RJ. 2008. Cryptic species diversity in a widespread bumblebee complex revealed using mitochondrial DNA RFLPs. Conservation Genetics 9: 653-666. doi:10.1007/s10592-007-9394-z

Panfilov DV. 1978. Keys to species of family Apidae - Bees. In: Medvedev GS (eds). Keys to species of insects in the European part USSR 3(1). Leningrad. Nauka. pp 508-519. (In Russian).

Pamilo P, Tengö J, Rasmont P, Pirhonen K, Pekkarinen A, Kaarnama E. 1997. Pheromonal and enzyme genetic characteristics of the Bombus lucorum species complex in northern Europe. Entomologica Fennica 7: 187-194.

Pekkarinen A, Teräs I, Viramo J, Paatela J. 1981. Distribution of bumblebees (Hymenoptera, Apidae: Bombus and Psithyrus) in eastern Fennoscandia. Notulae Entomologicae 61: 71-89.

Pesenko YuA. 1982. Principles and methods of quantitative analysis for faunistic research. Moscow. Nauka. 182 p. (In Russian).

Potapov GS, Kolosova YuS. 2011. Fauna and zoogeographical characteristic of bumblebees (Hymenoptera, Apidae: Bombus) of Khibiny. Evraziatskii entomologicheskii zhurnal 10(4): 483485. (In Russian).
Rabotnov TA. 1992. Phytocenology. Moscow. Moscow State University. 352 p. (in Russian).

Ranta E. 1982. Species structure of North European bumblebee communities. OIKOS 38: 202-209.

Rasmont P. 1984. Les bourdons du genre Bombus Latreille sensu stricto en Europe Occidentale et Centrale. Spixiana 7: 135-160.

Rasmont P, Scholl A, de Jonghe R, Obrecht E, Adamski A. 1986. Identité et variabilité des mâles de bourdons du genre Bombus Latreille sensu stricto en Europe Occidentale et Centrale (Hymenoptera, Apidae, Bombinae). Revue suisse de Zoologie 93: 661-682.

Rasmont P, Terzo M. 2010. Catalogue et clé des sous-genres et espèces du genre Bombus de Belgique et du nord de la France (Hymenoptera, Apoidea). Mons. Université de Mons. Laboratoire de Zoologie. $25 \mathrm{p}$.

Rasmont P, Iserbyt S. 2014. Atlas of the European Bees: genus Bombus. 3rd Edition. STEP Project. Atlas Hymenoptera. Accessed: http://www.zoologie.umh.ac.be// hymenoptera/page. asp?ID=169

Rasmont P, Franzén M, Lecocq T, Harpke A, Roberts SPM, Biesmeijer JC, Castro L, Cederberg B, Dvořák L, Fitzpatrick U, Gonseth Y, Haubruge E, Mahé G, Manino A, Michez D, Neumayer J, Ødegaard F, Paukkunen J, Pawlikowski T, Potts SG, Reemer M, Settele J, Straka J, Schweiger O. 2015. Climatic risk and distribution atlas of European bumblebees. Biorisk 10 (Special issue). 246 p. doi:10.3897/biorisk.10.4749

Ratnasingham, S. \& Hebert, P. D. N. (2007). BOLD: The Barcode of Life Data System (www.barcodinglife.org). Molecular Ecology Notes 7, 355-364. doi: 10.1111/j.1471-8286.2006.01678.x

Sambrook J, Russell DW. 2001. Molecular cloning. A laboratory manual. New York. Cold Spring Harbor Laboratory Press. 2100 p.

Scriven J, Woodall LC, Tinsley MC, Knight M, Williams PH, Carolan JC, Brown MJF, Goulson D. 2015. Revealing the hidden niches of cryptic bumblebees in Great Britain: implications for conservation. Biological Conservation 182: 126-133. doi:10.1016/j.biocon.2014.11.027

Shvartsman YuG, Bolotov IN. 2008. Spatio-temporal heterogeneity of the taiga biome in the Pleistocene continental glaciations. Ekaterinburg. The Ural Branch of the RAS. 302 p. (In Russian). Simon C, Frati F, Beckenbach A, Crespi B, Liu H, Flook P. 1994. Evolution, weighting, and phylogenetic utility of mitochondrial gene sequences and a compilation of conserved polymerase chain reaction primers. Annals of the Entomological Society of America 87(6): 651-701.

Skvortsov VE. 2000. Atlas of the vascular plants of the taiga zone in the European part of Russia. Moscow. Greenpeace of Russia. 587 p. (In Russian).

Svensson BG. 1979. Pyrobombus lapponicus auct., in Europe recognized as two species: P. lapponicus (Fabricius, 1793) and $P$. monticola (Smith, 1849) (Hymenoptera, Apoidea, Bombinae). Entomologica Scandinavica 10: 275-296.

Söderman G, Leinonen R. 2003. Suomen mesipistiäiset ja niiden uhanalaisuus. Helsinki. Tremex Press. 420 p.

Waters J, Darvill B, Lye GC, Goulson D. 2011. Niche differentiation of a cryptic bumblebee complex in the Western Isles of Scotland. Insect Conservation and Diversity 4(1): 46-52. doi:10.1111/j.1752-4598.2010.00101.x

Williams PH, Brown MJF, Carolan JC, An J-D, Goulson D, 
Aytekin AM, Best LR, Byvaltsev AM, Cederberg B, Dawson R, Huang J-X, Ito M, Monfared A, Raina RH, Schmid-Hempel P, Sheffield CS, Sima P, Xie Z-H. 2012. Unveiling cryptic species of the bumblebee subgenus Bombus s. str. world-wide with COI barcodes (Hymenoptera: Apidae). Systematics and Biodiversity 10: 21-56. doi:10.1080/14772000.2012.664574

Williams P.H. 2014. Bumblebees of the world. Accessed: http:// www.nhm.ac.uk/research-curation/projects/bombus/index.html

Editorial responsibility: Torkild Bakken.

This article is open-access and distributed under the terms of the Creative Commons Attribution 4.0 International license. This permits all non-commercial use, distribution, and reproduction in any medium, provided the original work is properly cited.

(http://creativecommons.org/licenses/by/4.0/). 